\title{
Effect of pesticides on available cationic micronutrients along with viable bacteria and fungi in soil
}

\author{
Paul, N. ${ }^{*}$, Sur, P., Das, D. K. and Mukherjee, D. \\ Department of Agricultural Chemistry and Soil Science, Bidhan Chandra Krishi Viswavidyalaya, Mohanpur, Nadia, West \\ Bengal PIN - 741252, India.
}

Accepted 3 May, 2013

\begin{abstract}
A pot culture experiment was conducted to investigate the effect of pesticides - 2,4-D (herbicide), endosulfan (insecticide) and dithane M-45 (fungicide) at their field application rates (1.0, 2.0 and $1.5 \mathrm{~kg}$ a.i ha ${ }^{-1}$ ), respectively, on the available Diethyl Triamine Pentacetic acid (DTPA) extractable copper (Cu), manganese (Mn) and zinc $(\mathrm{Zn})$ along with the population of viable bacteria and fungi in new alluvial soil (Typic haplustepts). The results reveal that as compared to control, 2,4-D effectuated a significant increase in the population of total bacteria (up to $21.1 \%$ ) and fungi $(33.7 \%)$ besides available $\mathrm{Cu}(21.7 \%)$ and $\mathrm{Zn}(119.4 \%)$ during later stages and $\mathrm{Mn}(\mathbf{8 . 7 \%})$ almost throughout the incubation period though there was significant progressive immobilization of $\mathrm{Cu}(17.7 \%)$ during initial stages. Endosulfan, contrarily caused significant reduction of total bacteria (up to $18.4 \%$ ), fungi (13.1\%) and immobilization of $\mathrm{Zn}$ (42.1\%) during later stages, $\mathrm{Cu}(10.3 \%)$ in the intermediary stage and $\mathrm{Mn}(64.7 \%)$ almost throughout. Dithane $\mathrm{M}-45$, however, resulted in a significant increase in available $\mathrm{Cu}(13.2 \%)$ and $\mathrm{Mn}(3.38 \%)$ in the intermediary stage in spite of inducing detrimental influence on fungi (18.7\%) and immobilization of $\mathrm{Zn}$ (12.9\%) during intermediary stage and $\mathrm{Mn}$ in early (3.0\%) and late stages (6.7\%) of incubation. Among the pesticides used in the investigation, the performance of herbicide $(2,4-D)$ was encouraging in almost every aspect.
\end{abstract}

Key words: Pesticide, DTPA extractable $\mathrm{Cu}, \mathrm{Mn}$ and $\mathrm{Zn}$, viable bacteria and fungi.

\section{INTRODUCTION}

Pesticides are chemicals generally used to eradicate pests. Among them, herbicides, insecticides and fungicides are widely adopted in present day agriculture for combating weeds, insects and pathogenic fungi, respectively. Irrespective of their mode of application - foliar or direct, the chemical get an entry to soil which is also the niche of innumerable micro flora and micro fauna indispensible for various biochemical transformations related to mineral nutrition of economically important plants. So it is imperative to study the behavior of pesticides in soil ecosystem comprising of biotic and abiotic entities (Van Ferd et al., 2003). Usually at recommended doses, the impact of most of pesticides is advantageous for the growth of microorganisms as evidenced by Das et al. (2003) Sigler and Turco (2002) and Zhang et al. (2010) with insecticides, fungicides and herbicides, respectively, on bacterial population and Das et al. (2005) and Devi et al. (2008) with insecticide and herbicide, respectively, on fungal population in soil. On the contrary, there are pesticides that adversely interfere with the metabolic processes of microorganisms resulting in diminutive growth as suggested by Ahmed and Ahmad (2006) Sigler and Turco (2002) and Shukla and Mishra (1997) with insecticides, fungicides and herbicides, respectively, on bacterial population and by Huijun et al. (2011) and Sigler and Turc (2002) and Gupta et al. (2011) with insecticides, fungicides and herbicides, respectively, on fungal population in soil. However, some of the pesticides exert non significant influence on microbial population in soil as revealed by Palaniswami et al. (2002); Sigler and Turco 
(2002) and Devi et al. (2008) with insecticides, fungicides and herbicides, respectively, on bacterial population and Palanaswami et al. (2002) and Ramesh and Nadanassababady (2005) for insecticide and herbicide, respectively, on fungal population in soil.

A few among the functional or metabolic nutrient required only in fractions but absolutely necessary for biotic entities, are therefore known as micronutrients. The importance of micronutrient in biotic life needs hardly any emphasis (Clarkson and Hanson, 1980) as they are cofactors of enzyme associated with metabolic processes regulating the growth, development and reproductive functions of life (Deb et al., 2009). Out of them, manganese is associated not only with chlorophyll synthesis but also as an integral component of respiratory enzymes (Deb et al., 2009). Manganese is, moreover, required in nitrogen metabolism (Brady and Well, 2002) while copper is an indispensable component of the enzymes - ascorbic acid oxidase, laccase and tyrosinase- involved in redox reactions (Deb et al., 2009). Copper is also involved in the utilization of ammonium nitrogen in plant metabolism (Marschner, 1995). Zinc, however, is linked to auxin synthesis (Deb et al., 2009) besides being a vital force behind proper carbon metabolism as well as water absorption in plants (Coyne, 2001).

Soil ecosystem is the active site of various biochemical transformations involved in plant nutrition wherein various microorganisms take an active part (Tate, 2000). Nutrient elements including micronutrients are transformed from the organic and inorganic components of soil by different groups of microorganisms through various biochemical mechanisms (Stevenson and Cole, 1986). The nutrients become accessible only if the rate of mineralization exceeds immobilization. Micro-organisms also regulate oxidation-reduction reactions and thereby determine accessibility or deficiency of nutrients. Pesticides interfere with soil ecosystem and thus impart differential influence on the availability of micronutrient elements (Davet, 2004).

In this context, increment in the level of available copper, manganese and zinc by the application of insecticides, fungicides and herbicides was reported by several workers (Jana et al., 1994; Wainwright and Pugh, 1974; Das, 1997). Contrarily, there are also reports revealing a reduction in the level of available copper, manganese and zinc by the application of insecticides, fungicides and herbicides in soil (Pal et al., 1979; Lane et al., 2012).

The diverging state of facts concurrently propounds an intensive investigation on effect of pesticides on available cationic micronutrients along with viable bacteria and fungi in soil.

\section{MATERIALS AND METHODS}

The investigation was carried out with earthen pots in the laboratory of the Department of Agricultural Chemistry and Soil Science, Bidhan Chandra Krishi Viswavidyalaya, Mohanpur, Nadia, West Bengal, India.
Table 1. Physico-chemical and microbiological properties of soil.

\begin{tabular}{lc}
\hline Soil characteristic & Status \\
\hline Type of soil & Alluvial \\
Soil taxonomy & Typic haplustepts \\
Coarse sand (\%) & 44.54 \\
Fine sand (\%) & 20.42 \\
Silt (\%) & 16.82 \\
Clay (\%) & 18.21 \\
Soil $\mathrm{p}^{\mathrm{H}}(1: 2.5 \mathrm{w} / \mathrm{v})$ in water & 6.82 \\
Organic carbon $\left(\mathrm{g} \mathrm{kg}^{-1}\right)$ & 7.00 \\
Total nitrogen $\left(\mathrm{g} \mathrm{kg}^{-1}\right)$ & 0.69 \\
Available phosphorus $\left(\mathrm{kg} \mathrm{ha}^{-1}\right)$ & 42.00 \\
Available potassium $\left(\left(\mathrm{kg} \mathrm{ha}^{-1}\right)\right.$ & 145.00 \\
Available cupper $\left(\mathrm{mg} \mathrm{kg}^{-1}\right)$ & 0.50 \\
Available manganese $\left(\mathrm{mg} \mathrm{kg}^{-1}\right)$ & 4.30 \\
Available zinc $\left(\mathrm{mg} \mathrm{kg}^{-1}\right)$ & 1.00 \\
Total bacteria $\left(\mathrm{cfu} \times 10^{6} \mathrm{~g}^{-1} \mathrm{dry}\right.$ soil) & 65 \\
Fungi (cfu $\left.\times 10^{4} \mathrm{~g}^{-1} \mathrm{dry} \mathrm{soil}^{-1}\right)$ & 50 \\
\hline
\end{tabular}

\section{Collection of soil}

Typical gangetic alluvium (inceptisol) soil was collected from the University Instructional Farm. Surface soil samples $(0$ to15 $\mathrm{cm}$ depth) gathered from monoculture (Kharif rice) cultivated field were air dried and passed through 80 mesh sieve. The physico-chemical and microbiological properties of the soil are delineated in Table 1.

\section{Experimental}

$100 \mathrm{~g}$ of soil was thoroughly mixed with urea, single super phosphate and muriate of potash at the rate of $100 \mathrm{Kg} \mathrm{N}, 50 \mathrm{Kg} \mathrm{P} \mathrm{O}_{5}$ and $50 \mathrm{~kg} \mathrm{~K}_{2} \mathrm{O} \mathrm{ha}{ }^{-1}$, respectively and placed in small earthen pots. Then each of three pesticides, endosulfan (35 EC) at $2.0 \mathrm{~kg}$ a.i. ha ${ }^{1}$, dithane-M 45 at $1.5 \mathrm{~kg}$ a.i. ha ${ }^{-1}$ and 2,4-D (38 EC) at $1.0 \mathrm{~kg}$ a.i. $\mathrm{ha}^{-1}$ were again blended, each separately with three replications. A triplicate control treatment (without any pesticide) was also maintained. The moisture content of soil in each pot was adjusted to $50 \%$ of water holding capacity of soil by compensating the loss in weight with deionized water on every alternate day. Then each pot was incubated at $37 \pm 1^{\circ} \mathrm{C}$ for 90 days.

\section{Sample collection and analysis}

Soil samples were collected from each of the respective pot on the $5^{\text {th }}, 10^{\text {th }}, 15^{\text {th }}, 30^{\text {th }}, 60^{\text {th }}$ and $90^{\text {th }}$ day of incubation for microbiological and chemical analysis. The colony forming units (cfu) of bacteria and fungi were enumerated by serial dilution and pour plate technique (Pramer and Schmidt, 1965) in asparagine-mannitol agar (Thronton, 1922) and rose bengal agar (Martin, 1950) media, respectively. The changes in the available cationic micronutrients (Zinc, Copper, and Manganese) were estimated by using atomic absorption spectrophotometer following the DTPA extraction method described by Lindsay and Norvell (1978).

\section{Statistical analysis}

The results were evaluated by analysis of variance (ANOVA), and 

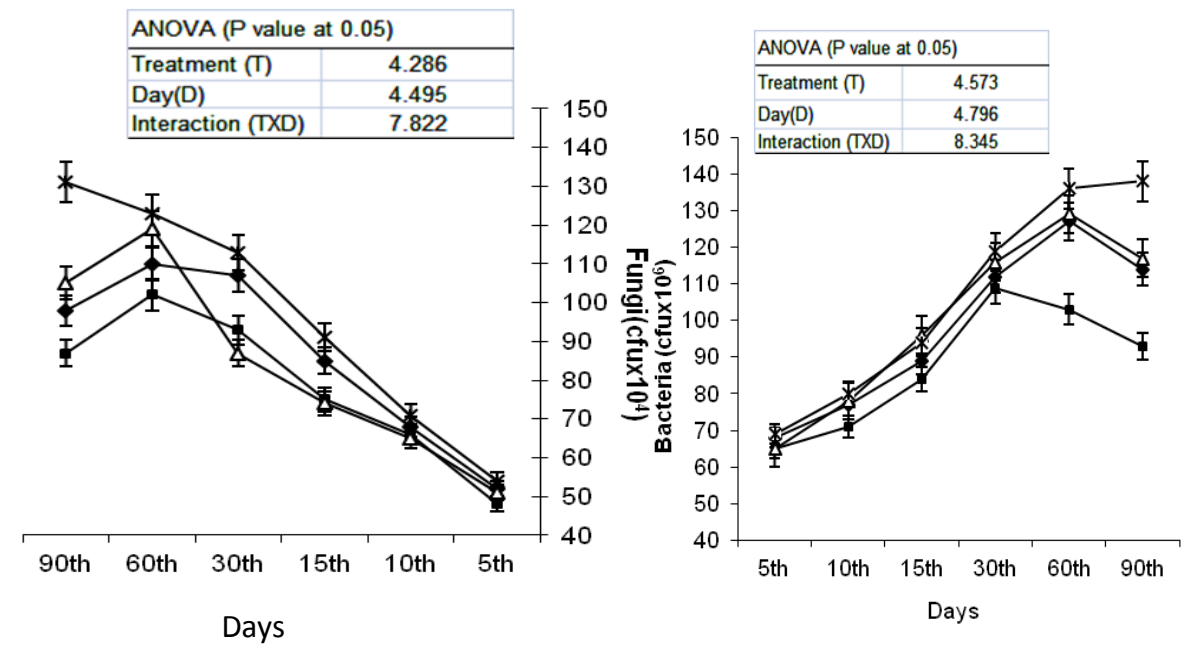

Figure 1. Effect of pesticides on the proliferation of total bacteria and fungi in soil:

$\rightarrow$ Control, $\longrightarrow$ Endosulfan, $\triangle-$ Dithane M-45, $\longleftarrow$ 2,4-D. (Mean of three replicated pots along with SD are shown)

the statistical significance $(P=0.05)$ of difference between means within factors (pesticides and incubation time) was evaluated using Completely Randomized Design following the method of Gomez and Gomez (1984).

\section{RESULTS AND DISCUSSION}

\section{Effect of pesticides on microbial population in soil}

Application of different types of pesticide in soil brought about differential influence on the population of total bacteria and fungi: the chemoheterotrophs, deriving energy and carbon from organic sources for cell synthesis (Figure 1). Similar observations were also reported earlier (Paul et al., 2010). Among the pesticides 2,4-D in spite of imparting non-significant influence during initial stages, effectuated a progressive significant enhancement from 7.1 and $11.8 \%$ on the $60^{\text {th }}$ day to 21.1 and 33.7 on the $90^{\text {th }}$ day on the population of total bacteria and fungi, respectively as compared to that of the control in soil. The results substantiate the findings of Minhang et al. (2001) manifesting the utilization of degraded products of herbicide as energy and nutrient sources by those in soil (Samanta et al., 2005). Moreover, the role of dead cells of susceptible organisms in furnishing energy and nutrient sources for the accelerated growth of organisms during the later stages of incubation cannot be ruled out (Agnihotri et al., 1981; Giri et al., 2006). Sustaining the report of Das et al. (1998), endosulfan brought about significant detrimental influence on bacterial population from the $60^{\text {th }}$ to $90^{\text {th }}$ day and fungal population from the $15^{\text {th }}$ and $90^{\text {th }}$ day. The highest reduction corresponding to $18.9 \%$ on the $60^{\text {th }}$ day and $13.1 \%$ on the $30^{\text {th }}$ day for bacteria and fungi, respectively, was registered, despite inducing non-significant effect during initial stages of incubation. Significant harmful effect during later stages in spite of non-significant influence during initial stages pointed out the activation process by which nontoxic substrates are converted to toxic molecules (Alexander, 1977; Roychawdhury et al., 1999). The fungicide - Dithane M-45, however, caused non-significant influence on the population of total bacteria in soil despite inducing a gradual significant reduction in fungal community from $12.9 \%$ on the $15^{\text {th }}$ day to $18.7 \%$ on the $30^{\text {th }}$ day as com-pared to that of control following non-significant influence during initial period which also enlighten the activation process. However the harmful effect of that chemical did not last long and there was a significant rise in fungal population on the $60^{\text {th }}$ day with the reflection of $8.2 \%$ increase over the control advocating not only the degradation of toxic chemicals but also rapid utilization of susceptible dead cells as energy and nutrient sources for the multiplication of succeeding generation of fungal cells in soil (Coyne, 2001).

\section{Effect of pesticides on available cationic micronutrients in soil}

Herbicide 2,4-D effectuated a gradual significant reduction in the level of available Cu from $13.5 \%$ on the $5^{\text {th }}$ day to $17.7 \%$ on the $15^{\text {th }}$ day of incubation as compared to that of control manifesting the progressive immobilization process by which available $\mathrm{Cu}$ was transformed to unavailable soil components including cellular components of microbes (Figure 2). After a pause (non-significant influence), there was a progressive increase in the level of the cationic micronutrient from $11.5 \%$ on the $60^{\text {th }}$ day to $21.7 \%$ on the $90^{\text {th }}$ day due to higher proliferation of total bacteria and fungi causing greater rate of mineralization of organic components of soil including the biotic entities while the pause pointed out the lag phase for synthesizing appropriate enzymes for the subsequent 

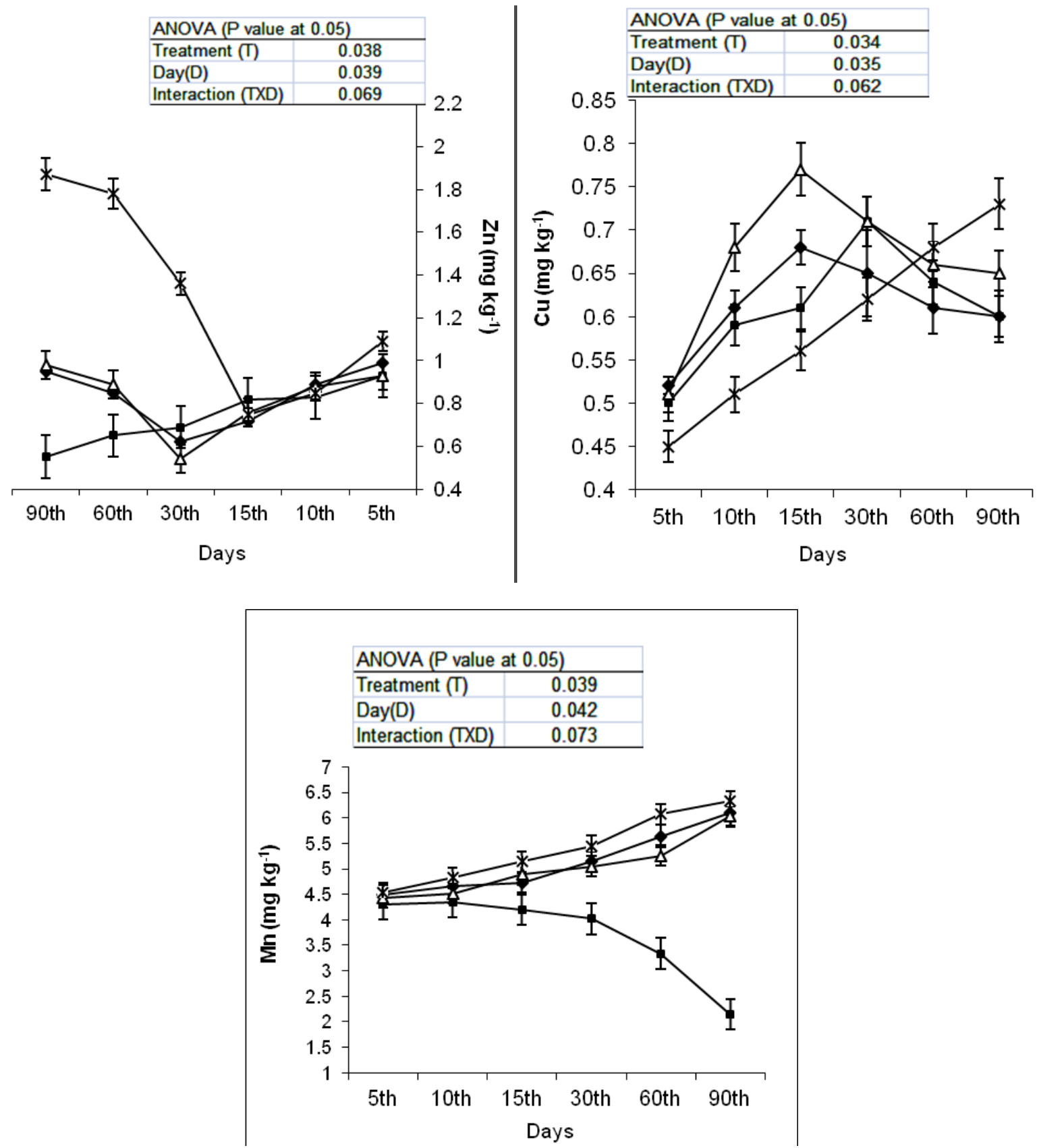

Figure 2. Effect of pesticides on DTPA extractable Zinc, Copper and Manganese in soil. For other explanation look at Figure 1.

mineralization process (SubbaRao, 2005). The herbicide also significantly augmented the level of available $\mathrm{Zn}$ from $119.4 \%$ on $30^{\text {th }}$ day to $96.8 \%$ on the $90^{\text {th }}$ day exhibiting a decline in the rate of mineralization. In addition there was a significant rise in the level of available $\mathrm{Mn}$ from $10^{\text {th }}$ to $90^{\text {th }}$ day with the highest on $15^{\text {th }}$ day corresponding to $8.7 \%$ increase over control. Endosulfan significantly decreased the level of available $\mathrm{Cu}$ to the extent of $10.3 \%$ on the $15^{\text {th }}$ day when compared with control due to slow rate of mineralization by microorganisms, in general, and lower proliferating fungi in particular. The insecti- cide registered $13.9 \%$ increase in level of available $\mathrm{Zn}$ on the $15^{\text {th }}$ day in spite of non-significant influence during the initial period. The extent of increment was dropped to $11.3 \%$ on the $30^{\text {th }}$ day and then there was a significant progressive increase in the immobilization of micronutrient from $23.5 \%$ on the $60^{\text {th }}$ day to $42.1 \%$ on the $90^{\text {th }}$ day. The chemical also caused progressive immobilization of $\mathrm{Mn}$ from $4.2 \%$ on the $5^{\text {th }}$ day to $64.7 \%$ on the $90^{\text {th }}$ day exhibiting slower rate of mineralization by the lower growing micro-organisms. Dithane $\mathrm{M}-45$ caused nonsignificant influence on available $\mathrm{Cu}$ on the $5^{\text {th }}$ day there- 
after the fungicide caused an, on and on, increase in the level of available Cu from $11.5 \%$ on the $10^{\text {th }}$ day to $13.2 \%$ on the $15^{\text {th }}$ day of incubation in spite of their non-significant or negative influence on bacteria and fungi suggesting abundance of micro-organisms is not the sole determining factor in predicting the rate of mineralization of nutrient element in soil (Das and Mukherjee, 1994). Contrarily, there was a significant fall of $12.9 \%$ in the level of $\mathrm{Zn}$ on the $30^{\text {th }}$ day as compared to that of control. The fungicide moreover brought about a significant diminution of $3.0 \%$ in the level of available $\mathrm{Mn}$ on the $10^{\text {th }}$ day. The fungicide again brought about a progressive increase in immobilization of available $\mathrm{Mn}$ from $1.8 \%$ on the $30^{\text {th }}$ day to $6.7 \%$ on the $60^{\text {th }}$ day following an increment of $3.4 \%$ on the $15^{\text {th }}$ day as compared to that of control.

\section{Conclusion}

From the results, it may be concluded that pesticides impart differential influence on available cationic micronutrients as well as viable bacteria and fungi in soil. Among the pesticides, the insecticide, endosulfan creates detrimental environment on soil ecosystem and so need utmost precaution while application. On the contrary, herbicide, in general, imparts beneficial influence on the available cationic micronutrients as well as microbial community. However, fungicide more or less caused both beneficial as well as harmful effect on available micronutrients and negative effect on fungi. Among the pesticides, 2,4-D generates the best soil environment.

\section{REFERENCES}

Agnihotri VP, Sinha AP, Singh K. (1981). Influence of insecticides on soil microorganisms and their biochemical activity. Pesticides, 15: 16 -24 .

Ahmed S, Ahmad MS (2006). Effect of insecticides on the total number of soil bacteria under laboratory and field conditions. Pakistan Entomologist. 28: 63-67.

Alexander M (1977). Introduction to Soil Microbiology. John Wiley Eastern Limited. New Delhi, India.

Brady NC, Weil RR (2002). The nature and properties of soils. Pearson Education, India.

Clarkson DT, Hanson JB (1980). The mineral nutrition of higher plants. In: Annual Review of Plant Physiology. 31: 239-298.

Coyne, MS (2001). Soil Microbiology, an exploratory approach. Delmar Publishers. Washington.

Das AC and Mukherjee D (1994). Effect of Insecticides on the availability of nutrients, $\mathrm{N}$ fixation and phosphate solubility in the rhizosphere soil of rice. Biology and Fertility of Soils. 18: 37-41.

Das AC, Chakravarty A, Sen G, Sukul P and Mukherjee D (2005). A comparative study on the dissipation and microbial metabolism of organophosphate and carbamate insecticides of orchaqualf and flavaquent soils of West Bengal. Chemosphere. 58: 579-584.

Das AC, Chakravarty A, Sukul P and Mukherjee D (2003). Influence and persistence of phorate and carbofuran insecticides on microorganisms in rice field. Chemosphere. 53: 1033-1037.

Das AC, Saha SK, Chakravarty A and Mukherjee D (1998). Effect of insecticides on the microbial population and their biochemical activites as influenced by organic matter in Typic Flavaquent soil. Indian Agriculturist. 42: 1-12.
Das DK (1997). Nutrient transformation and yield of rice (Oryza sativa L.) as affected by soil application of insecticides in its flooded ecosystem. Indian Journal of Agricultural Sciences, 67: 302-304.

Davet P (2004). Microbial Ecology of the Soil and Plant Growth. Science publishers, Inc, USA.

Deb DL, Sakal R, Datta SP (2009). Micronutrients. In: Fundamentals of Soil Science. Indian Society of Soil Science. Eds. NN Goswami, RK Rattan, G Dev, G Narayanaswamy, DK Das, SK Sanyal, DK Pal, DLN Rao. pp $461-490$.

Devi KMD, Beena S,Abraham CT (2008). Effect of 2,4-D residues on soil microflora. J, Tropical Agric. 46: 76-78.

Giri PK, Samanta A, Das S, Ghosh T, halder M, Mukherjee D (2006). Persistance of pesticides on the proliferation and potentialities of nitrogen fixing micro-organisms in soil. J. Interacademicia. 10: 349 353.

Gomez KA, Gomez AA (1984). Statistical procedures for Agricultural Research. John Wiley and sons. New York.

Gupta A, Aggarwal A, Mangla C, Kumar A, Tanwar A (2011). Effect of Herbicides Fenoxaprop-P-ethyl and 2, 4-D Ethyl-ester on Soil Mycoflora Including VAM Fungi in Wheat Crop. Indian J. Weed Sci. 43: $32-40$.

Huijun X, Fuwei G, Wei T, ShuGuang W (2011). A short term study on the interaction of bacteria, fungi and endosulfan in soil microcosm. Science of the Total Environment. 412/413: 375-379.

Jana TK, Chakraborty KK, Das B (1994). Effect of ekalux and aldrin on mobilization of manganese and iron in soil. Environment and Ecology. 12: 133 - 137.

Lane M, Lorenz N, Saxena J, Ramsier C, Dick RP (2012). Microbial activity, community structure and potassium dynamics in rhizosphere soil of soyabean plants treated with glyphosate. Pedobiologia. 55: 153-159.

Lindsay W, Norvell WA (1978). Development of a DTPA Test for Zn, Fe, $\mathrm{Mn}$ and Cu. J. Soil Sci. Society Am. 42: 421-428.

Marschner H (1995). Mineral nutrition of higher plants. Academic Press, New York.

Martin JP (1950). Use of acid, rose Bengal and streptomycin in the plate method for estimating soil fungi. Soil Sci. 69: 215-232.

Minhang YYF, Yun CZ, Weixiang W, Yuteng D, Min H, Ye YF, Chen ZY, Wu WX, Du YF (2001). Effect of butachlor on microbial populations and enzyme activities in paddy soil. Pesticides Food Contamination Agricultural Wastes. J. Environ. Sci. Health Part-B. 36: 581-595.

Pal SS, Barik S and Sethunathan N (1979). Effect of benomyl on iron and manganese reduction and redox potential in flooded soil. J. Soil Sci. 30: 155 - 159.

Palanaswami MS, Visalakshi A, Mohandas N, Das L (2002). Evaluation of soil application method of insecticides against Cylas formicarius (F.) and its impact on soil microflora in sweet potato ecosystem. J, Root Crops. 28: 55-60.

Paul N, Ghosh M, Das DK, Sur P, Mukherjee D (2010). Pesticidal impact on DTPA extractable iron vis-à-vis actinomycetes in soil. Indian Agriculturist. 54: 83-86.

Pramer D, Schmidt EL (1965). Experimental Soil microbiology, Burges Publishing Co. Minneapolis. 5, Minn.

Ramesh G, Nadanassababady T (2005). Impact of Herbicides on Weeds and Soil Ecosystem of Rainfed Maize (Zea mays L.). Indian J. Agric. Res. 39: 31-36.

Roychawdhury P, Sukul P, Chakravarty A, Mukherjee D (1999). Fluvalinate, a synthetic pyrethroid insecticide: its effect on microbial dynamics and their activity. Fresenius Environ. Bull. 8: 693-698.

Samanta A, Ghosh S, Haldar M, Mukherjee D, Ghosh RK (2005). Influence of herbicides on microorganisms and transformation of iron in rice rhizosphere soil. J. Interacademicia. 9: 528-532.

Sigler WV, Turco RF (2002). The impact of chlorothalonil application on soil bacteria and fungal populations as assessed by denaturing gradient gel electrophoresis. Appl. Soil Ecol. 21: 107-118.

Subba Rao NS (2005). Soil Microbiology. Oxford and IBH publishing Co. Pvt. Ltd. New Delhi.

Shukla AK, Mishra RR (1997). Influence of herbicides in microbial population and enzyme activity in potato (Solanum tuberosum)-field soil. Indian J. Agric. Sci. 67: 610-611.

Stevenson FJ, Cole MA (1986). Cycles of soil: Carbon, Nitrogen, Phosphorus, Sulfur, Micronutrients, John Wiley \& Sons, Inc. New York. 
Tate III RL (2000). Soil Microbiology. John Wiley Sons, Inc. New York. Thronton HG (1922). On the development of Standardized agar medium for counting soil bacteria with special regard to the repression of spreading colonies. Ann. Appl. Biol. 9: 241-274.

Van Ferd LL, Hoagland RE, Zablotowicz RM, Hall JC (2003). Pesticide metabolism in plants and microorganisms. Weed Sci. 51: 472-495.
Wainwright M, Pugh GJF (1974). The effect of fungicides on certain chemical and microbial properties of soils. Soil Biol. Biochem. 6: 263267.

Zhang C, Liu X, Dong F, Xu J, Zheng Y, Li J (2010). Soil Microbial Communities Response to Herbicide 2,4-dichlorophenoxyacetic Acid Butyl Ester. Eur. J. Soil Biol. 46: 175-180. 